\title{
Evaluation of STEP Co-operative Program from Project Management Perspective
}

\author{
Annapoorna M. S. ${ }^{1}$ and Pramod Kumar ${ }^{2}$ \\ ${ }^{1}$ Professor, CMR University, Bangalore, Karnataka, India. \\ ${ }^{2}$ Research Scholar, Rani Channamma University, Belgavi, Karnataka, India.
}

CITATION: Annapoorna, M. S. and Kumar, Pramod (2020), "Evaluation of STEP Co-operative Program from Project Management Perspective", MERC Global's International Journal of Management, Vol. 8, Issue 1, pp. 25-34.

ARTICLE HISTORY: Submitted: August 10, 2019, Revision received: September 21, 2019, Accepted: October 10, 2019

ARTICLE TYPE: Review paper

\begin{abstract}
Support to Training and Employment Programme (STEP) for Women is a flagship initiative conceived and executed by the Ministry of Women and Child Development, Government of India. This initiative intends to provide skills that give employability to women and to provide competencies and skills that enable women to become entrepreneurs. The purpose of the current study is to evaluate the STEP Co-operative Program from Project Management perspective and outline the adaptation of project management principles and methodology in rolling out the STEP initiative by one of the largest dairy co-operatives in India- Karnataka Co-operative Milk Producers' Federation Ltd $(K M F)$. The project management life cycle, performance domains and project management processes constitute the management framework. This paper provides an outlook on the STEP cooperative program with project management standards. The aim of the program is to deliver skill up-gradation and bring about social transformation for women in rural society. It has been observed that the program has brought out several benefits in the lifestyle of women leading to an increase in their selfesteem.
\end{abstract}

KEYWORDS: Training, Women employee, Project management, Government of India.

\section{BIBLIOGRAPHY}

1. Chaudhary, Balak and Upadhyaya, Mukul (2013), "Socio-Economic Impacts of Dairy Cooperative", Economic Journal of Development Issues, Vol. 15 \& 16, No. 1-2, pp. 15-23.

2. FAO (2012), Tools for Planning and Organising Cooperative Activities, http://www.fao.org/tempref/docrep/fao/005/x0475e/x0475e03.pdf.

3. GVI (1998), Women's Economic Empowerment and Vocational Training in Ghana, https://www.gvi.ie/programs/womens-empowerment-in-ghana/.

4. HRP (2010), Heifer Rearing Project, Development Support Agency of Gujarat, Tribal Development Department, Government of Gujarat, https://dsag.gujarat.gov.in/heifer-rearing-project-hrp.

5. IEG (2017), Women's Empowerment in Rural Community Driven Development Projects, IEG World Bank Group, http://ieg.worldbankgroup.org/sites/default/files/Data/Evaluation/files/lp_genderincdd_01272017.pdf.

6. KMF-STEP (1986), Karnataka Cooperative Milk Producers' Federation Limited, https://www.kmfnandini.coop/step.

7. Ling, K. Charles (2012), The Nature of the Cooperative: A Dairy Cooperative Case Study, USDA Rural Development, Research Report 224, April.

8. Maire Tecnimont (2019), India-Women empowerment project, https://www.mairetecnimont.com/en/sustainability/initiatives-projects/india-women-empowerment-project.

9. Milovanovic, Vladimir and Smutka, Lubos (2018), "Cooperative rice farming within rural Bangladesh", Journal of Co-operative Organisation and Management, Vol. 6, pp. 11-19.

10. NDDB (1965), National Dairy Development Board, https://www.nddb.org/didf/didf-in-brief. 
11. Planning Commission (2007), Evaluation Study on Integrated Dairy Development Project, Programme Evaluation Organisation, Planning Commission, Government of India, http://planningcommission.nic.in/reports/peoreport/peo/peo_iddp.pdf.

12. PMBOK (2017), The Glossary of Terms of PMBOK Guide, Sixth Edition, Project Management Institute, Inc.

13. PMI (2013), The Standard for Program Management, Third edition, Project Management Institute Inc., USA.

14. RICM (1986), Project on impact and comparative study of socio-economic development of dairy women phase I to IV of STEP Scheme, Regional Institute of Cooperative Management, http://www.ricmbangalore.com/.

15. Sama Taneja (2016), Women Empowerment, Danone Ecosystem Fund, https://www.danone.com/content/dam/danone-corp/about-us-impact/policies-andcommitments/en/2016/2016_04_21_WomenEmpowermentBooklet.pdf.

16. SDTP (2017), Skill Development and Training Programmes of Central Governments, http://planningcommission.gov.in/reports/genrep/rep_skillsch.pdf.

17. Sreenivasaiah, K. and Chellakumar, J. A. Arul (2016), "Role of Milk Cooperatives in Village Development of Karnataka State”, IOSR Journal of Business and Management, Vol. 18, Issue 8, pp. 23-29.

18. STEP Guidelines (2016), Support to Training and Employment Programme for Women Guidelines, http://wcd.nic.in/schemes/support-training-and-employment-programme-women-step.

19. Thomet, Nieves and Vozza, Alice (2010), Project Design Manual, A Step-by-Step Tool to Support the Development of Cooperatives and Other Forms of Self-Help Organisations, International Labour Organisation.

20. Vanishree, M; Sendhil, R.; Smita, S.; Chauhan, A. K.; Rashmi, H. M. and Ponnusamy, K. (2018), "Role of Dairy Cooperatives in Strengthening Value Chain of Liquid Milk and its Sustainability in Karnataka: Findings from Preliminary Study", Indian Journal of Economics and Development, Vol. 14, Issue 1, pp. 410-415.

21. WE-Care (2014), Women's Economic Empowerment and Care, https://policy-practice.oxfam.org.uk/ourwork/gender-justice/womens-economic-empowerment/we-care. 